Natural Hazards and Earth System Sciences (2003) 3: 615-623

(C) European Geosciences Union 2003

\title{
Reassessment of the historical seismic activity with major impact on S. Miguel Island (Azores)
}

\author{
D. Silveira, J. L. Gaspar, T. Ferreira, and G. Queiroz \\ Centro de Vulcanologia e Avaliação de Riscos Geológicos, Universidade dos Açores, Rua Mãe de Deus, 9501-801 Ponta \\ Delgada, Açores, Portugal
}

Received: 11 December 2002 - Accepted: 14 February 2003

\begin{abstract}
On account of its tectonic setting, both seismic and volcanic events are frequent in the Azores archipelago. During the historical period earthquakes and seismic swarms of tectonic and/or volcanic origin have struck S. Miguel Island causing a significant number of casualties and severe damages. The information present in historical records made possible a new macroseismic analysis of these major events using the European Macroseismic Scale-1998 (EMS-98).

Among the strongest earthquakes of tectonic origin that affected S. Miguel Island, six events were selected for this study. The isoseismal maps drawn for these events enabled the identification of areas characterized by anomalous values of seismic intensity, either positive or negative, to constrain epicentre locations and to identify some new seismogenic areas.

Regarding seismic activity associated with volcanic phenomena six cases were also selected. For each of the studied cases cumulative intensity values were assessed for each locality. The distribution of local intensity values shows that the effects are not homogeneous within a certain distance from the eruptive centre, the area of major impacts relates with the eruptive style and damages equivalent to high intensities may occur in Furnas and Sete Cidades calderas.

Combining all the historical macroseismic data, a maximum intensity map was produced for S. Miguel Island.
\end{abstract}

\section{Introduction}

The Azores archipelago is located in the North Atlantic Ocean where the American, African and Eurasian lithospheric plates meet (e.g. Searle, 1980) (Fig. 1). The so-called Azores Triple Junction is dominated by three main tectonic features: the Mid-Atlantic Ridge (MAR), which crosses the archipelago between the islands of Faial and Flores with a general N-S direction (Krause and Watkins, 1970; Steinmetz et al., 1976); the East Azores Fracture Zone, which extends E-W from the MAR to the Strait of Gibraltar (Krause, 1965), including the Gloria Fault (Laughton and Whitmarsh, 1974); and the Terceira Rift, which trends NW-SE along a line defined by Graciosa, Terceira and S. Miguel islands (Machado, 1959), that comprises, in a wide sense, the WNW-ESE fracture systems of Faial, Pico and S. Jorge islands. While the boundary between the American and the Eurasian and African plates is well established by the MAR, the location and nature of the eastern branch of the Azores Triple Junction is still controversial (e.g. Madeira and Ribeiro, 1990; Luís, 1996; Lourenço et al., 1998; Madeira, 1998; Miranda et al., 1998).

S. Miguel Island is located in the eastern segment of the Terceira Rift, showing a high diversity of volcanic and tectonic structures that includes three active trachytic central volcanoes with caldera (Sete Cidades, Fogo and Furnas) emplaced in the intersection of the NW-SE to WNW-ESE regional faults with an $\mathrm{E}-\mathrm{W}$ deep fault system thought to be a relic of a MAR transform fault (Queiroz, 1997) (Fig. 2). $\mathrm{N}-\mathrm{S}$ and NE-SW faults also occur in this context. Several cinder cones alignments link those major volcanic structures along NW-SE to WNW-ESE fractures. The easternmost part of the island comprises an inactive trachytic central volcano (Povoação) and an old basaltic volcanic complex (Nordeste).

Strong earthquakes have struck S. Miguel Island several times throughout more than five hundred years of history. Using the available historical documents and previous studies we reassessed the seismic intensities for the major events applying the European Macroseismic Scale-1998 (EMS-98). This allowed the investigation of the existence and origin of seismic intensity anomalies; relocate some of the proposed epicentres, and to produce the maximum historical seismic intensities map for the island. 


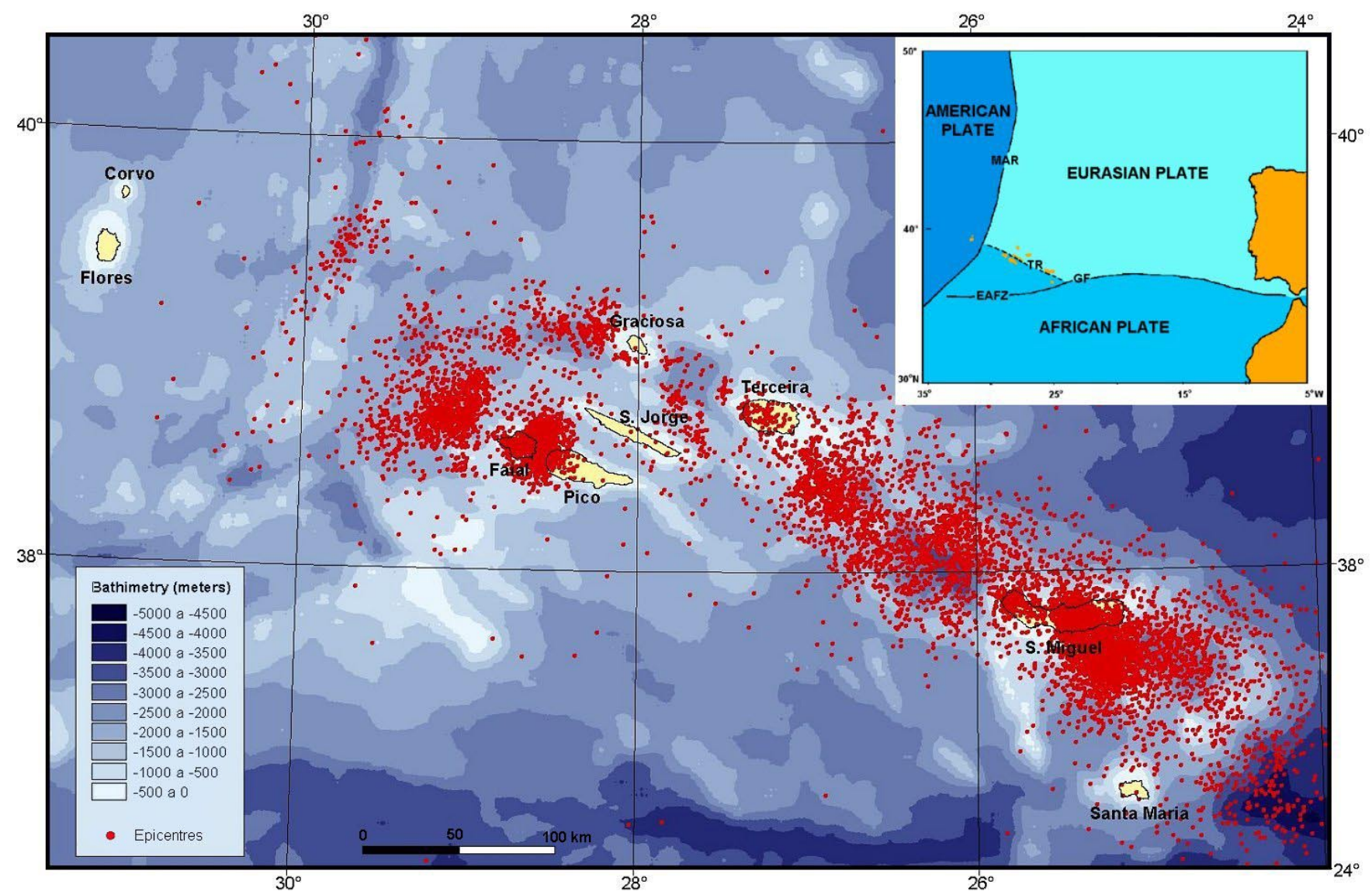

Fig. 1. Geographical location, tectonic setting and instrumental seismicity (1980-2001) of the Azores archipelago. Seismic data from SIVISA (2001). Bathymetry from Lourenço et al. (1998). Legend: MAR - Mid-Atlantic Ridge; EAFZ - East Azores Fracture Zone; TR Terceira Rift; GF - Gloria Fault.

\section{Historical data}

Despite some uncertainties about its discovery, it is known that the settlement of the Azores by the Portuguese started in the $2^{\text {nd }}$ quarter of the $15^{\text {th }}$ century. Historical documents reporting the natural hazards that have taken place in the Azores are dispersed in several libraries and archives. The first step was the gathering of copies of all the available historical documents, including individual chronicles, official reports, newspaper accounts and press notes. Since the time of the settlement until the middle of the $18^{\text {th }}$ century, the main sources of information were the chronicles written by Azorean priests (e.g. Frutuoso, 1522-1591†; Chagas, 1576-16??†; Monte Alverne, 1629-1726†; Cordeiro, 1641-1722†; Maldonado, 1644-1711†). Later on several authors compiled short descriptions about seismic and volcanic events, creating what can be considered as the earliest seismic catalogues of the archipelago (Mendonça, 1758; Araújo, 1801; Webster, 1821; Abranches 1877; Canto, 1878-1888; Bessone, 1932; Barata et al., 1989). After 1850 the main sources used were local newspapers. Macroseismic data of events that occurred in the $20^{\text {th }}$ century as well as previous works done by several authors were also used (e.g. Chaves,
1915; Agostinho, 1936, 1960; A.S.P., 1952; Dias, 1952; Ferreira, 1956; Silva, 1956; Costa Nunes et al., 1986; Cole et al., 1995; Queiroz, 1997; Wallenstein et al., 1998; Guest et al., 1999; Ferreira, 2000). The historical documents were organized and stored in a digital format to integrate the Azores Seismological Data Base.

The information found in historical records was often qualitative and sometimes misleading due to the use of different terms to characterise the same kind of effects as well as archaic expressions no longer of current use in Portuguese. Thus, a glossary was prepared in order to minimize misunderstandings. For some of the studied cases, the available data didn't allow to discriminate between damages produced either by seismic ground shaking or phenomena such as volcanic tremor, volcanic explosions or landslides. This was particularly true for the cases of the seismic swarms related with volcanic activity.

\section{Studied cases}

Among the major tectonic earthquakes that affected S. Miguel Island since its settlement, six events were selected 


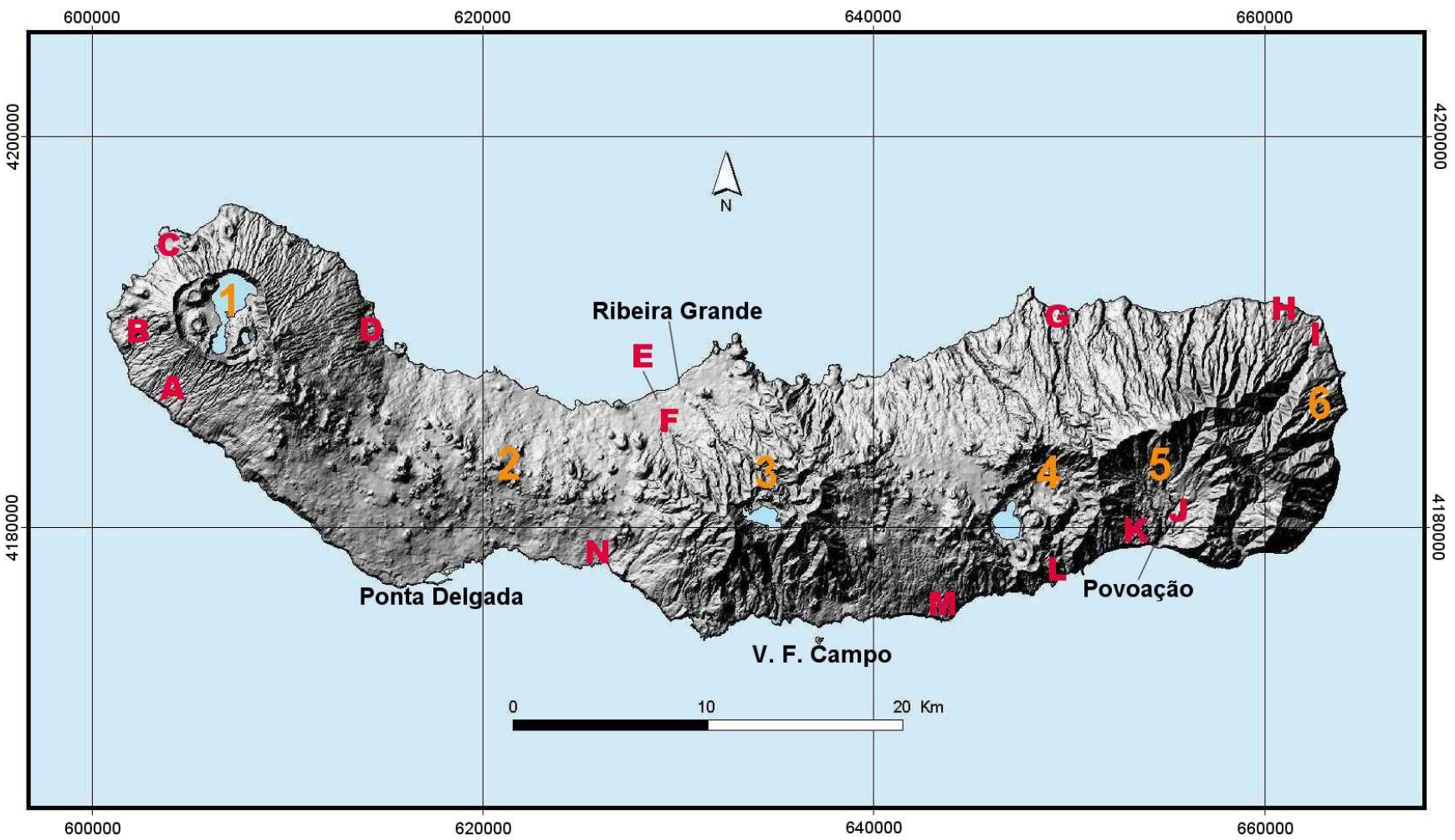

Fig. 2. Morphological features of S. Miguel Island: 1 - Sete Cidades Volcano; 2 - Picos Volcanic System; 3 - Fogo Volcano; 4 - Furnas Volcano; 5 - Povoação Volcano; 6 - Nordeste Volcanic Complex. Localities: A - Candelària; B - Ginetes; C - Mosteiros; D - Santo António; E - Ribeira Seca; F -Lomba de Santa Bárbara; G - Salga; H - Lomba da Fazenda; G - Ribeira do Guilherme; J - Lomba do Loução; K Lomba do Cavaleiro; L - Ribeira Quente; M - Ponta Garça; N - Santa Cruz; UTM coordinates).

for this study: 22 October 1522, 26 July 1591, 16 April 1852, 5 August 1932, 27 April 1935 and 26 June 1952 (Table 1). The damages caused by the seismic swarms associated with the volcanic eruptions of Fogo Volcano and Pico Queimado in 1563, Furnas Volcano in 1630, Pico do Paio in 1652, the 1811 submarine eruptions and the seismic swarms of 1713 and 1810 were also appraised (Table 2).

Intensities were assessed using the European Macroseismic Scale-1998 (EMS-98) (Grünthal, 1998). Although no extensive research has been carried out concerning the characterization of the building types, we assumed that the typical and most frequent edifices in the island should be assigned to vulnerability class A. Notwithstanding the fact that a small percentage of buildings of vulnerability class $\mathrm{B}$ and $\mathrm{C}$ also existed in the centre of main villages, the available data did not allow to discriminate their number and in what extent these buildings were affected.

The number of data points obtained for each event varies widely (Table 3 ). For some localities the intensities were assessed with a certain degree of uncertainty (e.g. V-VI meaning that intensity was V or VI). Another problem that arises from the historical sources is the fact that the described effects sometimes refer to a certain part of the island but with no particular reference to a definite locality (e.g. "in the eastern part of the island"). This is particularly true for the
1522 earthquake, where few local intensity data points were assessed although some general intensity information could be used for other parts of the island. Also the persistent lower or higher intensities associated with a certain locality were used as criteria to identify it as a possible anomalous area. All data was stored in a Geographic Information System (GIS) and the respective isoseismal maps were drawn (Fig. 3). Concerning the seismic swarms related with volcanic phenomena, the assessed intensity values for each episode reflect the cumulative effects observed in a certain period of time (Fig. 4).

\section{Discussion}

The isoseismal maps drawn for the studied earthquakes clearly show important seismic anomalies, some of which can be traced for more than one event.

Furnas and Sete Cidades calderas systematically present lower intensities than the ones expected (e.g. 1852, 1932, 1935 and 1952). Dias (1952) and Machado (1966) also identified these anomalies, which were interpreted as being related to the presence of shallow magma reservoirs (Machado, 1966). Results arisen from this work are in agreement with this interpretation. 
Table 1. Earthquakes selected as study cases

\begin{tabular}{|c|c|c|c|c|}
\hline Date & Time & $\begin{array}{c}\mathrm{I} \max \\
(\mathrm{EMS}-98)\end{array}$ & Victims & Effects \\
\hline 22 Oct. 1522 & $\begin{array}{l}\text { Two hours } \\
\text { before dawn }\end{array}$ & $\mathrm{X}$ & $\begin{aligned}>\sim & 3000 \text { deaths } \\
& (\text { up to } 5000)\end{aligned}$ & $\begin{array}{l}\text { - Countless landslides occurred, mainly in the central and } \\
\text { eastern part of the island. A huge landslide developed on a } \\
\text { hillside near Vila Franca do Campo which buried the village } \\
\text { a few minutes after the main shock, demolishing the houses } \\
\text { that were still standing, and killing most of its inhabitants. } \\
\text { Aftershocks also triggered landslides and debris flows. }\end{array}$ \\
\hline 26 July 1591 & Unknown & VIII-IX & "many" deaths & $\begin{array}{l}\text { - Landslides occurred. } \\
\text { - A new water spring flowed for four days. }\end{array}$ \\
\hline 16 April 1852 & $\begin{array}{l}\sim 22: 10 \\
(\text { local time })\end{array}$ & VIII & $\begin{array}{l}9 \text { deaths } \\
\text { Several people } \\
\text { seriously injuried }\end{array}$ & $\begin{array}{l}\text { - Landslides occurred, mainly on the slopes of Sete Cidades } \\
\text { volcano, along the northeast coast sea cliffs. } \\
\text { - The earthquake was felt on board of two ships, one of them } \\
\text { sailing NW from S. Miguel and the other SW from } \\
\text { Ponta Delgada. }\end{array}$ \\
\hline 5 Aug. 1932 & 19:24 (GMT) & VIII & $\begin{array}{l}\text { No casualties } \\
\text { Several people } \\
\text { injuried }\end{array}$ & $\begin{array}{l}\text { - More than } 3000 \text { homeless people. } \\
\text { - Landslides occurred at Lomba do Loução and along the } \\
\text { sea cliffs near Ponta Garça and Ribeira Quente. }\end{array}$ \\
\hline 27 April 1935 & $\begin{array}{c}17: 04 \\
\text { (local time) }\end{array}$ & IX & 1 death & $\begin{array}{l}\text { - Landslides occurred at Lomba do Loução and along the } \\
\text { sea cliffs near Ponta Garça and Ribeira Quente. } \\
\text { - The earthquake was felt on board of a ship sailing a } \\
\text { few miles south of Povoação. }\end{array}$ \\
\hline 26 June 1952 & 15:33 (GMT) & VIII & $\begin{array}{l}\text { No casualties } \\
\text { One child injuried }\end{array}$ & $\begin{array}{l}\text { - More than } 600 \text { homeless people. } \\
\text { Several landslides were triggered at the sea cliffs near } \\
\text { Ponta Garça and Ribeira Quente and at Lomba do Cavaleiro. }\end{array}$ \\
\hline
\end{tabular}

Other common negative intensity anomalies correspond to the Povoação and Ribeira Grande villages (e.g. 1522, 1932 and 1935). The existence of less vulnerable buildings (class B) in these areas might have contributed to the observed low seismic intensity values. However, it is also possible that some geological site effects played an important role in these cases. This is the interpretation for the lower intensity values normally observed in the Picos Volcanic System (e.g. 1932), essentially built by basaltic lava flows sequences.

Positive seismic intensity anomalies were also identified. Santo António, Lomba do Cavaleiro and Salga frequently show higher destruction levels than the surrounding areas (e.g. 1932 and 1935). Its location along prominent ridges suggests the influence of topographic effects. At Lomba de Santa Bárbara and Lomba da Fazenda the origin of the seismic anomalies is less clear, being the latest eventually related with the presence of the Ribeira do Guilherme well-defined NE-SW fault.

The analysis of the macroseismic data for the major tectonic earthquakes enabled new interpretations about their epicentral locations. The 1522 event is assumed to have occurred on land, NE of Vila Franca do Campo, in one of the main tectonic lines that crosses S. Miguel Island, where the most important landslides were triggered. Additionally, the distribution pattern of some low seismic intensity anomalies in the vicinity of Sete Cidades and/or Furnas volcanoes allowed constraining the epicentral locations of the 1852, 1932 and 1935 earthquakes.

Concerning the seismic swarms associated with volcanic phenomena, it is clear that the distribution of local intensity values is not homogeneous within a certain distance from the eruptive centre (e.g. 1563 and 1652). The level of damages is strongly related with the eruptive style.

Cumulative effects equivalent to high intensities occurred in Furnas and Sete Cidades calderas where negative seismic anomalies were identified in relation to earthquakes of tectonic origin (e.g. 1630 and 1810). This different behaviour may be due to shallower events and/or the proximity of the epicentral areas.

Merging the data from both tectonic and volcanic events, a maximum historical seismic intensity map was produced for S. Miguel Island (Fig. 5). As it can be seen, the obtained result is strongly controlled by the isoseismal lines of the 1522 tectonic earthquake, being the maximum intensity X zone centred in the Fogo Volcano area, with a general NW-SE distribution trend. The intensity IX zone in 
Table 2. Seismic swarms selected as study cases. Intensities reflect cumulative effects for the period presented in the first column

\begin{tabular}{|c|c|c|c|c|}
\hline Period & Volcanic phenomena & $\begin{array}{c}\mathrm{I}_{\max } \\
(\text { EMS-98) }\end{array}$ & Victims & Effects \\
\hline $\begin{array}{c}2 \text { Sept. } \\
\text { to } \\
8 \text { Sept. } 1630\end{array}$ & $\begin{array}{l}\text { Explosive trachytic subplinian } \\
\text { eruption in Furnas caldera and } \\
\text { dome growth in the latter erup- } \\
\text { tive phases }\end{array}$ & VIII & $\sim 200$ deaths & $\begin{array}{l}\text { - Most victims killed by surges, few died due to } \\
\text { house collapse. } \\
\text { - Severe destruction in Furnas, Ponta Garça } \\
\text { and Ribeira Quente. } \\
\text { - Landslides occurred in Ribeira Quente. }\end{array}$ \\
\hline $\begin{array}{c}\text { 17 June } \\
\text { to } \\
\text { 24 June } 1810\end{array}$ & $\begin{array}{l}\text { No volcanic phenomena observed, } \\
\text { probable submarine eruption }\end{array}$ & VIII & No casualties & $\begin{array}{l}\text { - A surface rupture opened near Mosteiros exten- } \\
\text { ding from the sea to the crater rim of Sete } \\
\text { Cidades Volcano. } \\
\text { - Many houses heavily damaged in Mosteiros, } \\
\text { Ginetes and Candelária. }\end{array}$ \\
\hline $\begin{array}{c}\text { 13 June } \\
\text { to } \\
\text { 22 June } 1811\end{array}$ & $\begin{array}{l}\text { Surtseyan eruption off the NW } \\
\text { coast of S. Miguel on the flank } \\
\text { of Sete Cidades volcano }\end{array}$ & IX & No casualties & $\begin{array}{l}\text { - Landslides occurred on the northwest coast of the } \\
\text { island. } \\
\text { - A new island was formed - Sabrina. Sea erosion } \\
\text { made it disappear in October of the same year. } \\
\text { - Many houses completely destructed in Mosteiros, } \\
\text { Ginetes and Candelária. }\end{array}$ \\
\hline
\end{tabular}

Table 3. Data points assessed for each event as used for Fig. 3. Each data point represents one locality, for which several reports were analysed

\begin{tabular}{rcccccccccc}
\hline \multicolumn{1}{c}{ Date } & III & IV & V & VI & VII & VIII & VIII-IX & IX & X & Total \\
\hline 22 Oct. 1522 & & & & & 1 & 1 & & 2 & 2 & 6 \\
26 July 1591 & & & & & & 2 & & & 2 \\
16 April 1852 & & 1 & 3 & 8 & 21 & 5 & & & 38 \\
5 Aug. 1932 & 2 & 8 & 11 & 10 & 7 & 3 & & & 41 \\
27 April 1935 & 7 & 13 & 16 & 7 & 1 & & 1 & 45 \\
26 June 1952 & 1 & 5 & 12 & 4 & 1 & & & \\
\hline
\end{tabular}



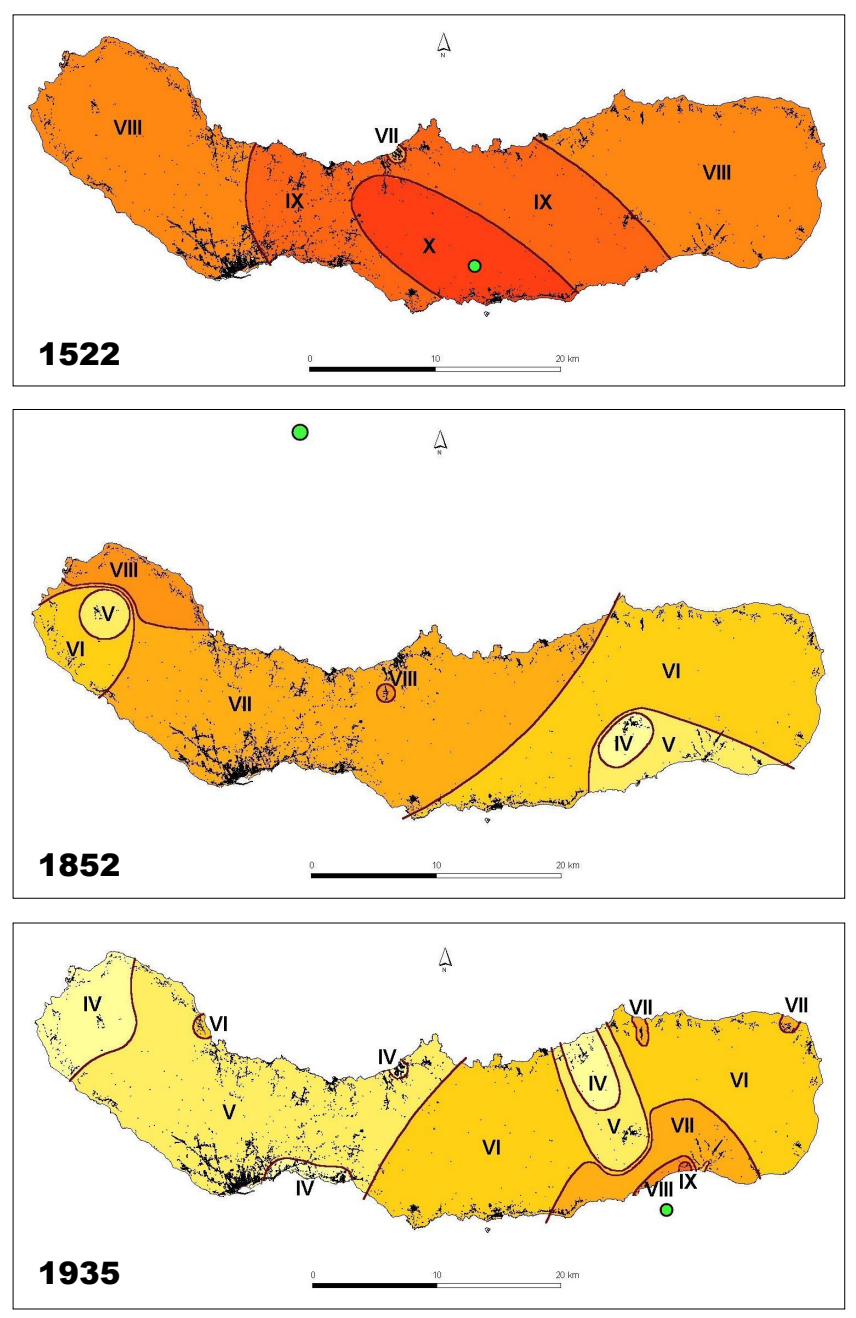
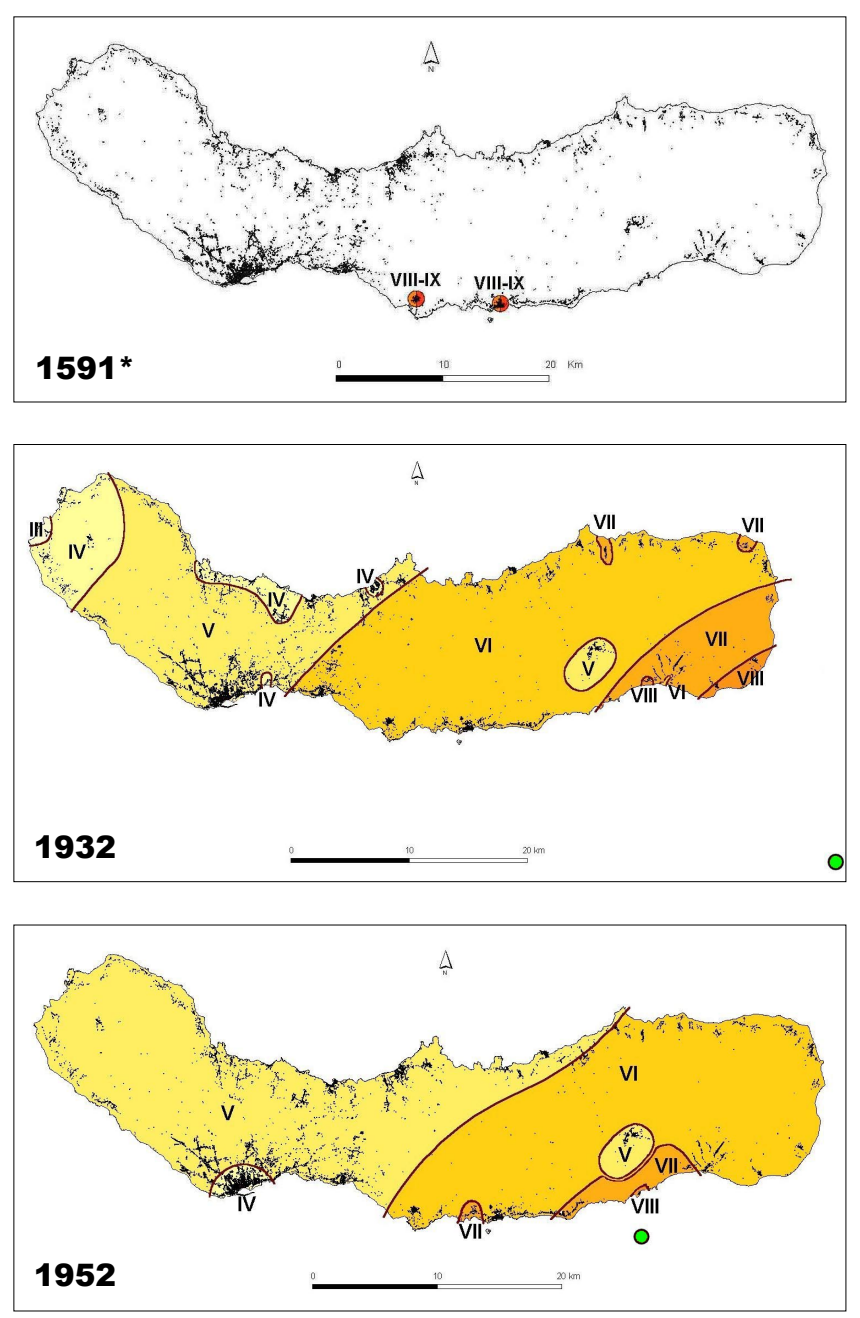

Fig. 3. Isoseismal maps drawn for the studied earthquakes: green dots - epicentres; black dots - urban areas; * insufficient data to draw isoseismal lines, epicentre probably off the south coast of the island.

the western part of the island is the result of the seismic activity that accompanied the volcanic episodes offshore Sete Cidades Volcano.

\section{Conclusions}

The study of historical documents related with the destructive earthquakes that have stricken S. Miguel Island revealed to be an important tool for seismic risk assessment. New insights about the epicentral location of major events contributed to evaluate the active character of main tectonic lines and highlight seismogenic areas not defined yet by the short time period of instrumental seismicity in the archipelago.

The results of macroseismic studies based on historical records are useful as a first approach to set guidelines for the development of future works. This is the case for the identified seismic intensity anomalous areas, where further studies should be carried out in order to verify their origin and discuss their implications in risk analysis. The studied cases can also be used as possible scenarios to model the impact of future events and set up emergency and land use planning measures.

This kind of study should be extended to all the islands of the archipelago to complement the instrumental seismic data information. Tectonic, paleoseismological and geological surveys should be carried out to identify field evidences of fault movements related with the studied historical earthquakes. 

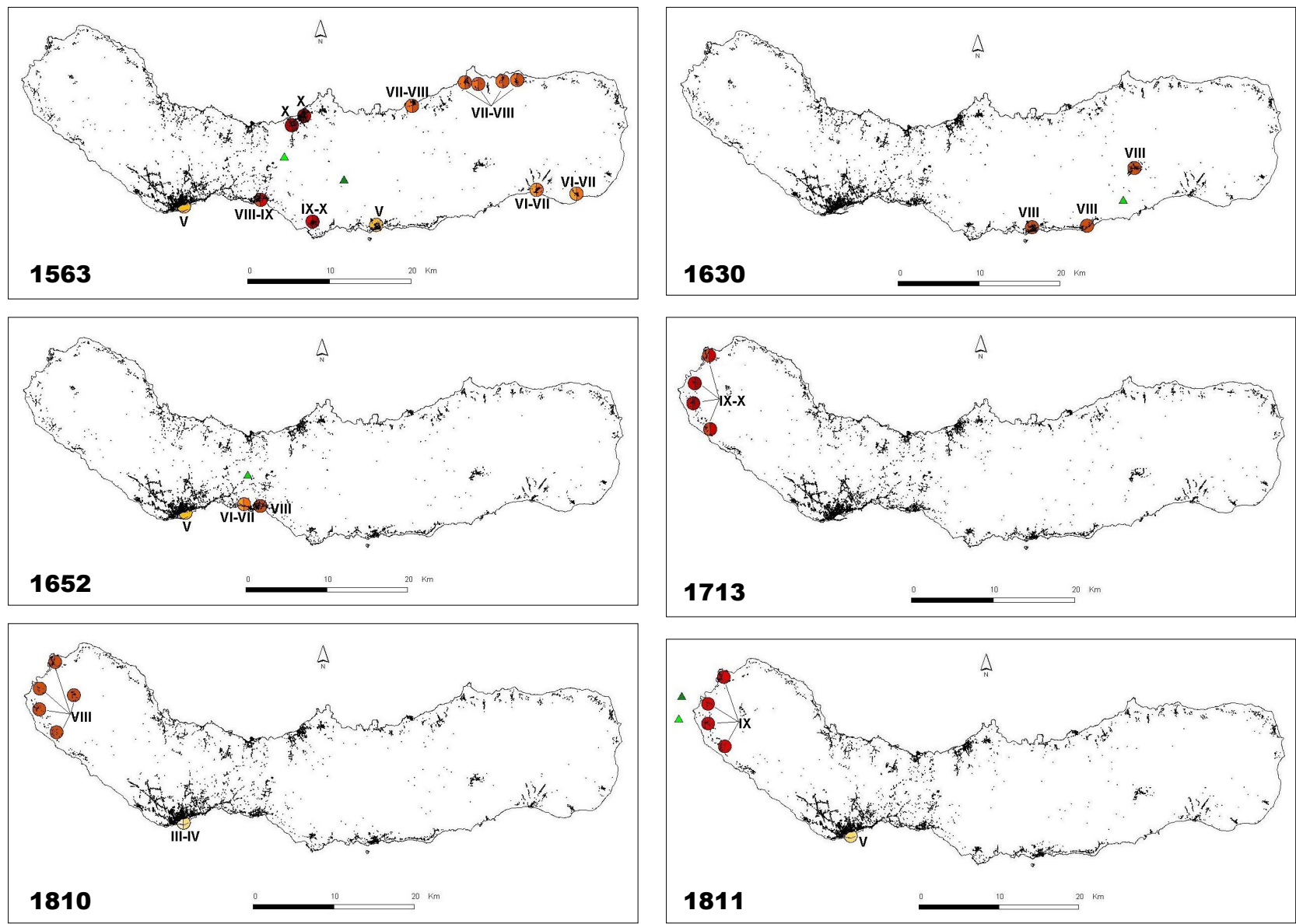

Fig. 4. Local intensity maps for the studied seismic swarms. For some localities the intensities were assessed with a certain degree of uncertainty (e.g. III-IV meaning that intensity was III or IV). $\triangle \boldsymbol{\Delta}$ - eruptive centres; black dots - urban areas.

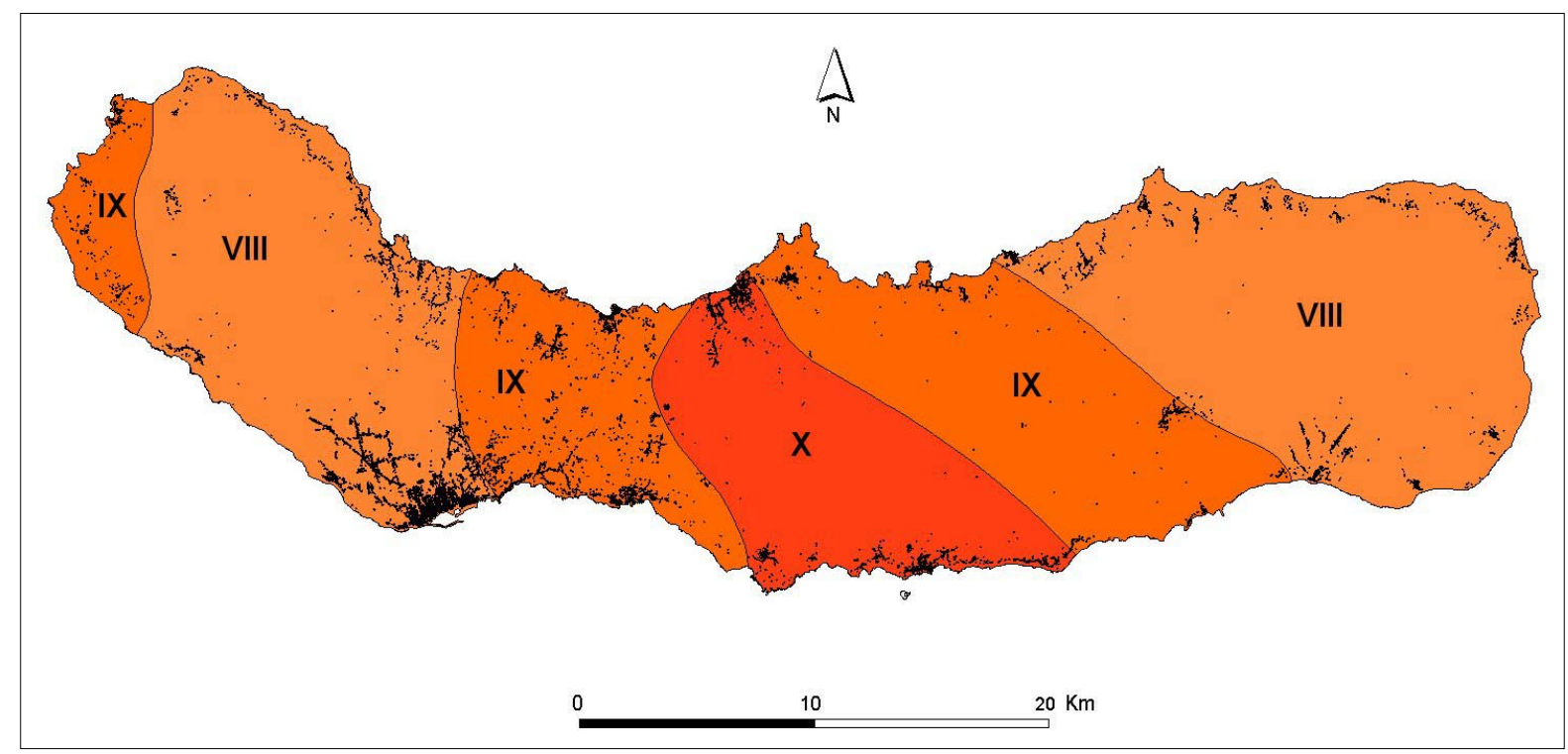

Fig. 5. Maximum historical intensity map of S. Miguel Island using the EMS-98 (black dots - urban areas). 


\section{References}

Abranches, J. C.: Convulsões da Terra, $1^{\mathrm{a}}$ ed. Ponta Delgada: Typographia de Manoel Corrêa Botelho, 212, 1877.

Agostinho, J.: Tectónica, sismicidade e vulcanismo das ilhas dos Açôres, Açoreana, Angra do Heroísmo, Vol.I: 2, 86-98, 1936.

Agostinho, J.: Actividade vulcânica nos Açores, Açoreana, Angra do Heroísmo, 5, 362-478, 1960.

A.S.P.: Anuário Sismológico de Portugal, Dir. H. Amorim Ferreira, $N^{\circ} 6$ - Ano de 1952, Lisboa: Serviço Meteorológico Nacional, I, 1955.

Araújo, L. A.: Memoria chronologica dos tremores mais notaveis e irrupções de fogo, acontecidos nas ilhas dos Açores: com a relaçao dos tremores que houverao nesta ilha Terceira... Acrescenta-se a noticia de hum fenomeno observado no dia 25 de Junho.... $1^{a}$ ed. Lisboa: Thypographia Chalcographica e Litteraria do Arco do Cego, 24, 1801.

Barata, M. R. T., Braga, M. L., Wagner, M. N., Guerra, B., Alves, J. F., and Neto, J.: Sismicidade de Portugal: estudo da documentação dos séculos XVII e XVIII - apêndice documental, $1^{\mathrm{a}}$ ed. Lisboa: Gabinete de Protecção e Segurança Nuclear do Ministério do Planeamento e da Administração do Território, II, 336, 1989.

Bessone, P.: Dicionário cronológico dos Açôres, $1^{\mathrm{a}}$ ed. Cambridge, Massachusetts, USA: Edição do autor, 446, 1932.

Canto, E.: Vulcanismo nos Açores, Arquivo dos Açores, Ponta Delgada: Universidade dos Açores, I: (1878); II: (1880); III: (1881); V: (1883); IX: (1887); XI: (1890).

Chagas, Fr. D.: 1576-16??†- Espelho cristalino em jardim de várias flores, $1^{\mathrm{a}}$ ed. (Angra do Heró́smo)(Ponta Delgada): Direcção Regional dos Assuntos Culturais: Centro de Estudos Doutor Gaspar Frutuoso da Universidade dos Açores, 731, 1989.

Chaves, F. A.: Erupções submarinas nos Açores: informações que os navegantes podem prestar sobre tal assunto. $1^{\mathrm{a}}$ ed. Lisboa: Tipografia d'A Modesta, 47, 1915.

Cole, P. D., Queiroz, G., Wallenstein, N., Gaspar, J. L., Duncan, A. M., and Guest, J. E.: An historic subplinian / phreatomagmatic eruption: the 1630 AD eruption of Furnas volcano, São Miguel, Azores, J. of Volcanology and Geothermal Res., Amsterdam 69, 117-135, 1995.

Cordeiro, A.: Historia insulana das ilhas a Portugal sugeytas no oceano occidental, $3^{\mathrm{a}}$ Ed. (reimpressão fac-similada da $1^{\mathrm{a}}$ ed. de 1717) Região Autónoma dos Açores: Secretaria Regional da Educação e Cultura, 528, 1981.

Costa Nunes, J., Martins, A., and Oliveira, C. S.: Sismicidade histórica e instrumental do arquipélago dos Açores: sismos sentidos no período 1444-1980, Catálogo preliminar, Relatório INMG/LNEC: 1986, (não paginado), 1986.

Dias, A. A. M.: Os sismos de 26 de Junho de 1952 e a sismicidade de S. Miguel, Ponta Delgada: (s.n.), 10, 1952.

Ferreira, H. A.: Macrossismos sentidos em Portugal no período de 1901-1954, Boletim da Ordem dos Engenheiros, Lisboa, V, $\mathrm{N}^{\circ}$ 1, Memória $\mathrm{N}^{\circ}$ 128, 1-10, 1956.

Ferreira, T.: Caracterização da actividade vulcânica da ilha de S. Miguel (Açores): vulcanismo basáltico recente e zonas de desgasificação, Avaliação de riscos, Ponta Delgada: Departamento de Geociências da Universidade dos Açores, Tese de Doutoramento em Geologia na especialidade de Vulcanologia, 247, 2000.

Frutuoso, G.: 1522-1591†: Livro Quarto das Saudades da Terra, In Frutuoso, G. $-\ll$ Saudades da Terra $\gg .2^{\mathrm{a}}$ ed. Ponta Delgada: Instituto Cultural de Ponta Delgada, II, 1981.
Grünthal, G., (ed.): European Macroseismic Scale 1998, Cahiers du Centre Européen de Géodynamique et de Séismologie, Luxembourg, 15, 1-99, 1998.

Guest, J. E., Gaspar, J. L., Cole, P. D., Queiroz, G., Duncan, A. M., Wallenstein, N., Ferreira, T., and Pacheco, J. M.: Volcanic geology of Furnas Volcano, São Miguel, Azores, J. Volcanol., Amsterdam, 92, 1-29, 1999.

Krause, D.: East and West Azores Fracture-Zones in the North Atlantic, in: Submarine geology and geophysics, (Eds.) Witthard, W. E. and Bradshaw, R., London Butterworths Publ., 163$172,1965$.

Krause, D. and Watkins, N.: North Atlantic crustal genesis in the vicinity of the Azores, Geophys. J. of the Royal Astron. Soc., UK, 19, 261-283, 1970.

Laughton, A. and Whitmarsh, R.: The Azores-Gibraltar plate boundery, in: Geodinamics of Iceland and the North Atlantic Area, Kristjansson, L., $1^{\text {a }}$ ed. Dordrecht, Holland: D. Reidel, 63-81, 1974.

Lourenço, N., Miranda, J. M., Luis, J. F., Ribeiro, A., Mendes Victor, L. A., Madeira, J., and Needham, H. D.: Morpho-tectonic analysis of the Azores Volcanic Plateau from a new bathymetric compilation of the area, Marine Geophys. Res., Netherlands, 20, 141-156, 1998.

Luís, J.: Le plateau des Açores et le point triple associé: analyse géophysique et évolution, Paris: Université Paris VII, Thèse de Doctorat, spécialité Géophysique Interne, 196, 1996.

Machado, F.: Submarine pits of the Azores plateau, Bull. Volcanol., Série II, Tome XXI, 109-116, 1959.

Machado, F.: Anomalias das intensidades do terramoto de S. Miguel (Açores) em 1522, Boletim do Museu e Laboratório Mineralógico e Geológico da Faculdade de Ciências, Lisboa, 10, 2, 109-117, 1966.

Madeira, J.: Estudos de neotectónica nas ilhas do Faial, Pico e S. Jorge: uma contribuição para o conhecimento geodinâmico da junção tripla dos Açores, Lisboa: Departamento de Geologia da Faculdade de Ciências da Universidade de Lisboa, Tese de Doutoramento em Geologia na especialidade de Geodinâmica Interna, 428, 1998.

Madeira, J. and Ribeiro, A.: Geodynamic models for the Azores triple junction: a contribution from tectonics, Tectonophysics, UK, 184, 405-415, 1990.

Maldonado, Pe. M. L.: 1644-1711†: Fenix angrence, $1^{\mathrm{a}}$ ed. Angra do Heroísmo: Instituto Histórico da Ilha Terceira, V 2 717 , 1990.

McKenzie, D. P.: Active tectonics of the Mediterranean region, Geophys. J. of the Royal Astronom. Soc., UK, 30, 109-185, 1972.

Mendonça, J. J. M.: Historia universal dos terramotos que tem havido no Mundo, de que ha noticia, desde a sua creaçaõ até o seculo presente: com huma narraçam individual do terremoto do primeiro de Novembro de $1755 . .$. e huma dissertaçaõ phisica sobre as causas geraes dos terremotos.... $1^{\mathrm{a}}$ ed. Lisboa: Offic. de Antonio Vicente da Silva, (12), 272, 1758.

Miranda, J. L., Mendes Victor, L. A., Simões, J. Z., Luís, J. F., Matias, L., Shimamura, H., Shiobara, H., Nemoto, H., Mochizuki, H., Hirn, A., and Lépine, J. C.: Tectonic setting of the Azores Plateau deduced from a OBS survey, Marine Geophys. Res., Netherlands, 20, 171-182, 1998.

Monte Alverne, A.: 1629-1726†: Crónicas da Província de S. João Evangelista das Ilhas dos Açores, $1^{\mathrm{a}}$ ed. Ponta Delgada: Instituto Cultural de Ponta Delgada, II, 520, 1961.

Queiroz, G.: Vulcão das Sete cidades (S. Miguel, Açores): história 
eruptiva e avaliação do hazard, Ponta Delgada: Departamento de Geociências da Universidade dos Açores, Tese de Doutoramento em Geologia na especialidade de Vulcanologia, 226, 1997.

Ribeiro, A.: Tectónica de placas: aplicação à sismotectónica e à evolução da fronteira de placas Açores-Gibraltar, Geonovas, Lisboa, 1:4, 87-98, 1982.

Searle, R.: Tectonic pattern of the Azores spreading centre and triple junction, Earth and Planetary Science Letters, Amsterdam, 51, 415-434, 1980.

SIVISA: Carta de Sismicidade dos Açores, no período de 1980 a 2001, 2002.

Silva, M. A. V.: Apontamentos duma visita à ilha de S. Miguel para estudo dos efeitos os abalos sísmicos de 5 de Agosto de 1932 e
27 de Abril de 1935, Boletim da Ordem dos Engenheiros, Lisboa, V, N 4, Memória n ${ }^{\circ} 142,1-8,1956$.

SREA: Serviço Regional de Estatística dos Açores, Censos 2001.

Steinmetz, L., Hirn, A., Sapin, M., Whitmarsh, R., Moreira, V.: Zone of P Wave attenuation beneath the crest of Mid-Atlantic Ridge, Bull Soc. Geol. France, $N^{\circ} 4$.

Wallenstein, N., Duncan, A. M., Almeida, H., and Pacheco, J.: A Erupção de 1563 do Pico do Sapateiro, S. Miguel (Açores) Procedings da $1^{\mathrm{a}}$ Assembleia Luso-Espanhola de Geodesia e Geofísica (CD-ROM), Almeria, Espanha, (1998).

Webster, J.: A description of the St. Michael, $1^{\text {st }}$ ed. Boston: R. P.\&C. Williams Ed., 1821. 